\title{
A COMPARATIVE STUDY OF CONTINUOUS VERSUS INTERRUPTED EPISIOTOMY REPAIR AFTER VAGINAL BIRTH IN PRIMIGRAVIDAE
}

\author{
By
}

\section{Mohamed Fawzy Abd El-Halem Amin, Hassan Abdrabboh and Mohamed Farahat}

Department of Obstetrics and Gynecology, Faculty of Medicine, Al-Azhar University

E-mail: drmidomido2015@gmail.com

\begin{abstract}
Background: The use of continuous sutures are associated with lower short-term pain intensity assessed compared to the interrupted sutures; 2 days after repair and 10 days after repair.

Objective: To assess the effects of continuous versus interrupted suturing methods on short and long term postpartum maternal morbidity experienced by primiparous women following repair of episiotomy after vaginal birth.

Patients and methods: This comparative study was conducted in the Emergency Unit of Obstetrics and Gynecology at Desouk general Hospital. The study involved 200 primigravid women prepared for vaginal delivery with episiotomy).

Results: In the current study, episiotomy repair with continuous sutures was more economic; it required a significantly shorter time and lesser number of Vicryl sutures. Repair of episiotomy wound using continuous suturing technique of the vaginal mucosa and perineal muscles results in a better post-procedural pain recovery.

Conclusions: Continuous suturing technique consumed significantly shorter procedure time and less cost owing to fewer vicryl sutures.
\end{abstract}

Keywords: Continuous suturing, Interrupted sutures technique, Repair, Episiotomy.

\section{INTRODUCTION}

The presence of perineal tears and use of episiotomy are among the few indicators available for measuring maternal outcomes associated with childbirth and obstetrical quality of care (Lacross et al., 2018).

Episiotomy is the surgical enlargement of the posterior aspect of the vagina by an incision to the perineum during the last part of the second stage of labor (MoyaJiménez et al., 2019).
Episiotomy is performed on an individualized basis. Episiotomy is considered when the clinical circumstances place the patient at high risk of a third or fourth degree laceration or when the fetal heart tracing is of concern and hastening vaginal delivery is warranted. Mediolateral episiotomy is associated with a lower risk of third and fourth degree laceration than a median episiotomy (Bhuria, 2013).

The aim of this study was to assess the effects of continuous versus interrupted 
suturing methods on short and long term postpartum maternal morbidity experienced by primiparous women following repair of episiotomy after vaginal birth.

\section{PATIENTS AND METHODS}

This comparative study was conducted in the Emergency Unit of Obstetrics and Gynecology at Desouk General Hospital. The study involved 200 primigravid women prepared for vaginal delivery with episiotomy.

\section{Inclusion Criteria:}

Vaginal birth, vertex presentation without instrumentation.,primigravida patients of at least 37 weeks gestation. Single pregnancy in active labor and no past history of vaginal or perineal operation.

\section{Exclusion Criteria:}

Factors interfering with wound healing like severe anemia, diabetes mellitus or patients on corticosteroids or immunosuppressants. Generous episiotomy with extension into levatorani muscles. Second and third degree perineal tears and malposition and Malpresentation

\section{The participants were randomly divided in to 2 equal groups:}

Group (A): Episiotomy was repaired with continuous sutures involving the vaginal mucosa, perineal muscles and subcutaneous tissue with vicryl $2 / 0$. Skin was repaired by subcuticular stitches with vicryl 3/0.

Group (B): Episiotomy was repaired with interrupted sutures of vaginal mucosa. Perineal muscles were repaired by interrupted sutures with vicryl $2 / 0$ and skin was repaired by subcuticular stitches with vicryl $3 / 0$.

\section{All patients were subjected to:}

1. Complete history taking including personal, medical, present, obstetric, past and family history.

2. Careful clinical examination (general, abdominal and local).

3. CBC, HbA1C.

4. Ethical considerations are confirmed with informed written consent.

Suture Material: Identical suture material of multifilament delayed absorbable material (Vicryl 2-0) was used for vaginal mucosa and perineal muscles. Absorbable material (Vicryl 3-0) was used for skin closure in both groups. Immediately after episiotomy repair, the number of suture material was counted and the time taken with repair was recorded in minutes.

In the second day postpartum before discharge, women were evaluated for pain using Verbal Rating Score (VRS). Verbal rating score consists of score from 0 to 3 $(0=$ no pain, $1=$ mild, $2=$ moderate, $3=$ severe pain). Ten days after delivery the woman was evaluated in the outpatient clinic for perineal pain (using VRS), wound infection, edema and redness after 3 months of repair, the woman was interviewed in outpatient clinic of for observing pain perception with lying, walking and sitting posture using (VRS).

\section{Statistical Methods:}

Statistical analysis was performed using Microsoft ${ }^{\circledR}$ Excel $^{\circledR}$ version 2010 and Statistical Package for the Social Sciences $\left(\right.$ SPSS $\left.^{\circledR}\right)$ for Windows ${ }^{\circledR}$ version 15.0. Continuous data were to be presented as 


\section{A COMPARATIVE STUDY OF CONTINUOUS VERSUS INTERRUPTED...}

range, mean and standard deviation (if parametric); or range, median and interquartile range (if non-parametric). Dichotomous or categorical data were to be presented as number and percentage. The used tests were t-test, Mann-whitney $U$ test ,chi square test and Fisher exact test.

\section{RESULTS}

The two groups were comparable regarding maternal age $(p=0.364)$ and gestational age at delivery $(\mathrm{p}=0.101)$ (Table 1). Episiotomy repair required a significantly shorter time in the continuous suture groups $(\mathrm{p}<0.001)$. One ampule of Vicryl sutures was used for skin closure in all cases $(n=200)$. However, the interrupted sutures group required significantly higher number of Vicryl sutures $(p<0.001)$ used for repair of vaginal mucosa and perineal muscles (Table 1).

Table (1): Maternal age and gestational age of the two studied groups

\begin{tabular}{|c|c|c|c|}
\hline Groups & $\begin{array}{c}\text { Group A } \\
\text { n=100 }\end{array}$ & $\begin{array}{c}\text { Group B } \\
\mathbf{n = 1 0 0}\end{array}$ & P value \\
\hline Maternal Age (years) & $25.1 \pm 3.2$ & $24.7 \pm 3.3$ & 0.365 \\
\hline Gestational Age (weeks) & $38.2 \pm 1.0$ & $38.5 \pm 1.2$ & 0.056 \\
\hline Procedure time & $9.2 \pm 2.8$ & $14.3 \pm 3.5$ & $<0.001$ \\
\hline No. of sutures (ampoules)* & $1(1-2)$ & $2(1-3)$ & $<0.001$ \\
\hline
\end{tabular}

* Data were expressed as median (range)

Pain intensity assessed using VRS was significantly higher in the interrupted sutures group 2 days after repair $(\mathrm{p}<$ $0.001)$ and 10 days after repair $(\mathrm{p}<$
0.001). However, 3 months after repair, the perineal pain intensity was comparable in the two groups $(\mathrm{p}=0.490)$ (Table 2$)$.

Table (2): Verbal Rating Scale score after the episiotomy repair in the two studied groups

\begin{tabular}{|c|c|c|c|}
\hline \begin{tabular}{l|l} 
Verbal rating & Groups \\
scale system & \\
\end{tabular} & $\begin{array}{c}\text { Group A } \\
\mathbf{n}=\mathbf{1 0 0}\end{array}$ & $\begin{array}{c}\text { Group B } \\
\mathbf{n}=\mathbf{1 0 0}\end{array}$ & $P$ value \\
\hline $\begin{array}{l}\text { Day } 2 \\
\end{array}$ & $1(1-2)$ & $2(1-3)$ & $<0.001$ \\
\hline Day 10 & $0(0-2)$ & $1(0-1)$ & $<0.001$ \\
\hline After 3 months & $0(0-1)$ & $0(0-1)$ & 0.490 \\
\hline
\end{tabular}


Table (3): Pain intensity during the 2nd post-procedural day in the two studied groups

\begin{tabular}{|c|c|c|}
\hline $\begin{array}{ll}\text { nd } & \text { post procedural pain } \\
\text { Pain intensity }\end{array}$ & $\begin{array}{c}\text { Group A } \\
\mathbf{n}=\mathbf{1 0 0}\end{array}$ & $\begin{array}{c}\text { Group B } \\
\mathbf{n}=\mathbf{1 0 0}\end{array}$ \\
\hline Mild & $61(61 \%)$ & $17(17 \%)$ \\
\hline Moderate & $39(39 \%)$ & $73(73 \%)$ \\
\hline Severe & $0(0 \%)$ & $10(10 \%)$ \\
\hline P value & \multicolumn{2}{|c|}{$<0.001$} \\
\hline \multicolumn{3}{|l|}{$10^{\text {th }}$ post procedural pain } \\
\hline None & $65(65 \%)$ & $25(25 \%)$ \\
\hline Mild & $33(33 \%)$ & $75(75 \%)$ \\
\hline Moderate & $2(2 \%)$ & $0(\% 0)$ \\
\hline P VALUE & \multicolumn{2}{|c|}{$<0.001$} \\
\hline
\end{tabular}

Following the episiotomy repair no cases of bleeding, severe swelling, hematoma, perineal extension, or rectal injury was recorded. Few women had wound dehiscence, and infection (Table 4). There was no significant difference between the two groups regarding the frequency of wound complications. During the later follow up visit after 3 months, more women complained of dyspareunia in the interrupted sutures group, however the difference between the two groups was not statistically significant $(p=0.121)($ Table 3).

Table (4): Complications of episiotomy repair in the two studied groups

\begin{tabular}{|l|c|c|c|}
\hline Complications $\quad$ Groups & $\begin{array}{c}\text { Group A } \\
\mathbf{n = 1 0 0}\end{array}$ & $\begin{array}{c}\text { Group B } \\
\mathbf{n = 1 0 0}\end{array}$ & P value \\
\hline Wound Infection & $8(8 \%)$ & $6(6 \%)$ & 0.579 \\
\hline Wound dehiscence & $2(2 \%)$ & $3(3 \%)$ & 1.000 \\
\hline Dyspareunia & $8(8 \%)$ & $15(15 \%)$ & 0.121 \\
\hline
\end{tabular}

\section{DISCUSSION}

For those women who sustain perineal injury, it is important that skilled operators repair the trauma, and that they use the best suturing techniques and materials, in order to minimize any associated problems. In addition to the extent of trauma, the surgical skills, the type of material used and the suturing technique have an important effect on the degree of maternal morbidity. The best technique for this repair should be quick, with less use of suture material and minimal pain (Kettle et al., 2012).

The ideal technique for perineal repair would require less use of materials and less time to perform which produces less pain in both short and long term (Valenzuela et al., 2012).

The aim of this study was to assess the effects of continuous versus interrupted suturing methods on short and long term postpartum maternal morbidity experienced by primiparous women following repair of episiotomy after vaginal birth. The study was designed as a randomized controlled trial. In the two groups, we have also used identical suture material for episiotomy repair. Multifilament delayed absorbable material (Vicryl 2-0), was used for vaginal mucosa and perineal muscles. 


\section{A COMPARATIVE STUDY OF CONTINUOUS VERSUS INTERRUPTED...}

A prospective, randomized study compared the impact of Vicryl-Rapide and chromic catgut for episiotomy repair in relation to perineal pain and wound healing. . Compared to the chromic catgut group, the Vicryl-Rapide group was associated with less pain (32.5\% vs. $57 \%$ ) and a less need for analgesia $(15.5 \%$ vs. 0.5 ) at 3-5 days in addition to significant reduction in the wound indurations, uncomfortable stitches and wound dehiscence and a better wound healing. No significant difference was noted in the perineal pain at 6 weeks postpartum. Wound infections (3.5\%) and wound resuturing $(2 \%)$ were seen in the chromic catgut group and they were absent in the Vicryl-Rapide group (Bharathi et al., 2013).

A systematic review compared different types of suture material for repairing episiotomy and perineal tears. These materials included catgut, standard synthetic, rapidly absorbing synthetic, glycerol impregnated catgut sutures, and monofilament sutures. In general, compared with catgut, standard synthetic sutures were associated with less pain up to three days after delivery; and less analgesia up to ten days postpartum. More women with catgut sutures required resuturing compared with synthetic sutures. There was no evidence of significant differences between groups for long-term pain (three months after delivery) or for dyspareunia at three, or at six to 12 months (Kettle et al., 2010).

Kokanall et al. (2011) reported that the continuous suturing techniques for episiotomy closure, compared to interrupted methods, are associated with less short-term pain, are quicker and also need less suture material. Kindberg et al. (2011) concluded that interrupted, inverted stitches for perineal repair leaving the skin unsutured appear to be equivalent to the continuous suture technique in relation to perineal pain, wound healing, patient satisfaction, dyspareunia and need for resuturing.

Similar results were reported in an Iranian study; continuous and interrupted episiotomy repair resulted in similar pain severity and episiotomy repair rate. However, continuous repair required shorter time of repair and fewer threads; thus reduce required time, energy, and costs (Hasanpoor et al., 2012).

Similarly, continuous technique was found to be quick to perform and consumed less suture material without the risk of increased complications. However, no statistically significant difference was noted regarding pain in the short or long term (Mahmood and Anwar, 2013).

The economic concern was more pronounced in a study performed in Pakistan. The authors preferred continuous suture technique as it was less costly as less suture material is required without compromising the outcome. They even found that chromic catgut is still an effective suture material for perineal repair in resource poor countries based on similar outcome to polyglactin 910 (Perveen and Shabbir, 2012).

Kettle et al. (2012) did a systematic review to assess the effects of continuous versus interrupted absorbable sutures for repair of episiotomy and second-degree perineal tears following childbirth. The systematic review was concluded by the observation that continuous suturing techniques for perineal closure, compared 
with interrupted methods, are associated with less short-term pain, need for analgesia and suture removal. Furthermore, there is also some evidence that the continuous techniques used less suture material as compared with the interrupted method (one packet compared to two or three packets, respectively).

An Indian study - similar to the current study - compared continuous versus interrupted techniques found less repair time and suture material were noted in continuous technique group. Continuous suture techniques were associated with less pain for up to 10 days postpartum with no difference in the severity of pain in long term period (Dash et al., 2013).

The advantage of less short-term pain was reported to be even lower in another randomized study. The authors compared continuous with interrupted techniques with two different types of synthetic absorbed suture materials; monofilament and multifilament types in women having vertex delivery with right mediolateral episiotomy. The perineal pain scores, the repair time, the amount of suture were significantly less in the continuous technique groups. However, there was no difference in pain score at 10th day and during sexual intercourse 6 weeks after the delivery (Kokanall et al., 2011).

\section{CONCLUSION}

Repair of episiotomy wound using continuous suturing technique of the vaginal mucosa and perineal muscles resulted in a better post-procedural pain recovery. Short-term pain intensity 2 and 10 days after repair was significantly less pronounced in association with continuous suturing compared to interrupted suturing technique.
Dyspareunia rate show non-significant difference regarding continuous or interrupted suture technique Continuous suturing technique consumed significantly shorter procedure time and less cost owing to fewer vicryl sutures.

\section{REFERENCES}

\section{Bharathi A, Reddy DB and Kote} GS (2013): A prospective randomized comparative study of vicryl rapide versus chromic catgut for episiotomy repair. J Clin Diagn Res., 7(2):326-30.

2. Bhuria VR (2020): Shoulder Dystocia. Labour Room Emergencies, Springer, Singapore, Pp. 333-349.

3. Dash S, Nanda SS, Behera $A$ and Mishra B (2013): Continuous Versus Interrupted Sutures for Episiotomy Wound and Perineal Tear Repair. Sch J App Med Sci., 1(6):710-713.

4. Hasanpoor S, Bani S, Shahgole $\mathbf{R}$ and Gojazadeh $M$ (2012): The Effects of Continuous and Interrupted Episiotomy Repair on Pain Severity and Rate of Perineal Repair: A Controlled Randomized Clinical Trial. Journal of Caring Sciences, 1(3):165-171.

5. Kettle $\mathbf{C}$, Dowswell $\mathbf{T}$ and Ismail KM (2012): Continuous and interrupted suturing techniques for repair of episiotomy or second-degree tears. Cochrane Database Syst Rev., 11:CD000947.

6. Kindberg S, Stehouwer $\mathrm{M}$, Hvidman $L$ and Henriksen TB (2011): Postpartum perineal repair performed by midwives: a randomised trial comparing two 


\section{A COMPARATIVE STUDY OF CONTINUOUS VERSUS INTERRUPTED...}

suture techniques leaving the skin unsutured. Br J Obstet Gynaecol., 115:472-9.

7. Kokanalı D, Ugur M, Kuntay Kokanalı M, Karayalcın $R$ and Tonguc E (2011): Continuous versus interrupted episiotomy repair with monofilament or multifilament absorbed suture materials: a randomised controlled trial. Arch Gynecol Obstet., 284(2):275-80.

8. LaCross A, Groff $M$ and Smaldone A (2018): Obstetric anal sphincter injury and anal incontinence following vaginal birth: a systematic review and meta analysis. J Midwifery Womens Health, 60: 37- 47.

9. Mahmood S and Anwar S (2013): Continuous Versus Interrupted Sutures for Episiotomy Wound
Repair Journal of Surgery Pakistan (International), 18(1): 7-11.

10. Moya-Jiménez LC (2019): New approach to the evaluation of perineal measurements to predict the likelihood of the need for an episiotomy." International Urogynecology Journal, 30(5): 815821.

11. Perveen $F$ and Shabbir $T$ (2012): Perineal repair: comparison of Suture materials and suturing Techniques. Journal of Surgery Pakistan (International), 14 (1): 23-28.

12. Valenzuela $P$, Saiz Puente $M$, Valero J, Azori'n $\mathbf{R}$ and Ortega $\mathbf{R}$. (2012): Continuous versus interrupted sutures for repair of episiotomy or second-degree perineal tears: a randomized controlled trial. BJOG., 116:436-441. 


\section{مقارنة بين اصلاح شث العجان المتصل مقابل المتقطع لابي البكريات بعد الولادة الطئن المبيعية}

محمد فوزي عبدالحليم أمين، حسن أحمد عبدربه، محمد محمد إبراهيم فرحات

قسم النساء والتوليد، كلية الطب، جامعة الأزهر

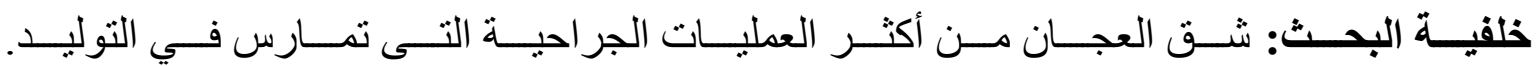
ولا تز ال تقنية إصلاح شق العجان مسألة نقاش.

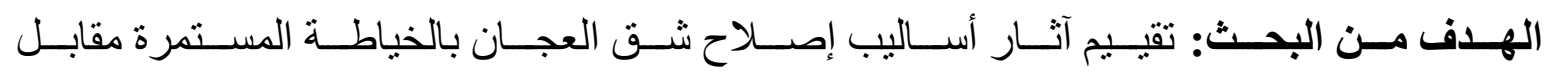

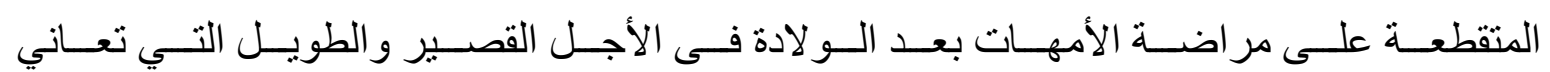
منها النساء بعد الإصلاح.

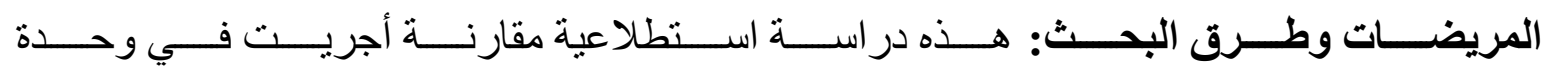

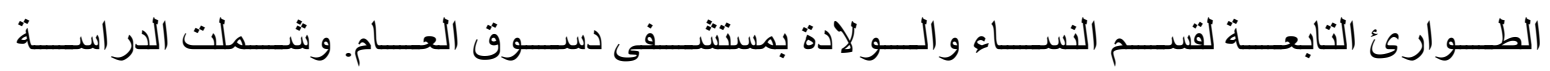

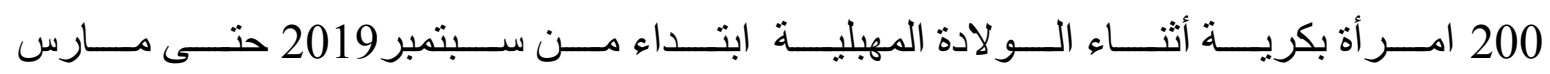

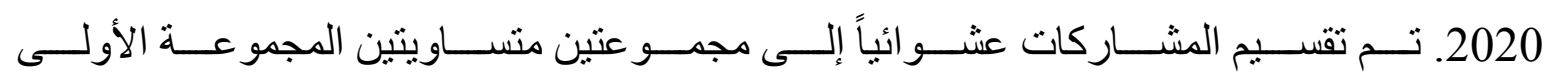

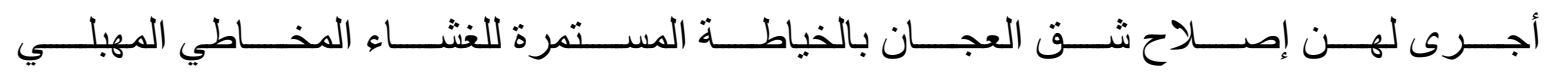

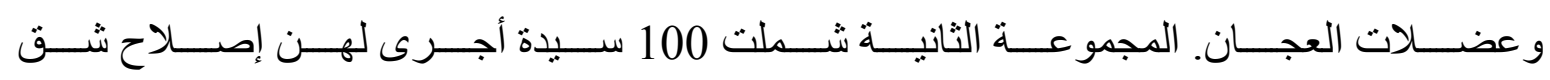

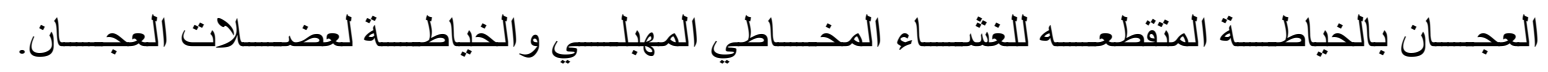

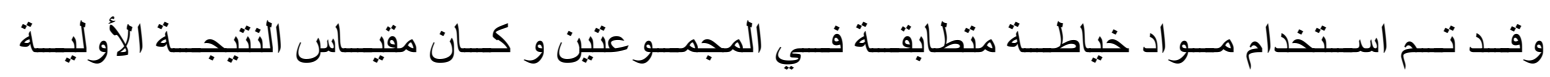

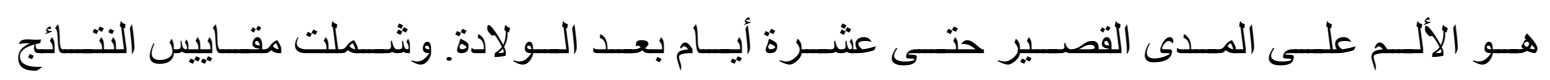

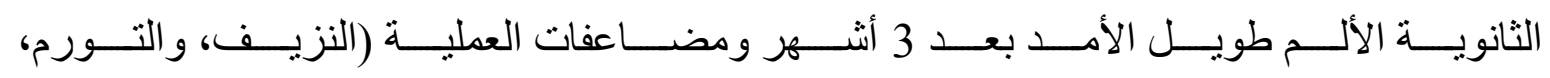

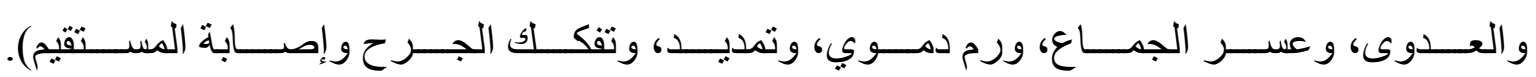
تم تقييم الألم باستخدام نقاط التقييم اللفظي.

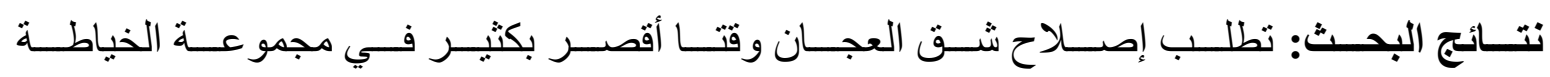

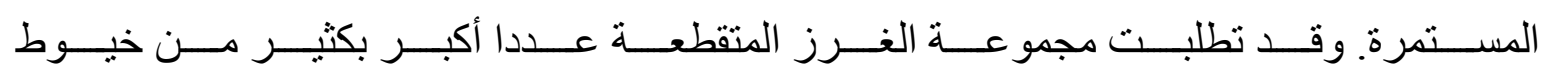

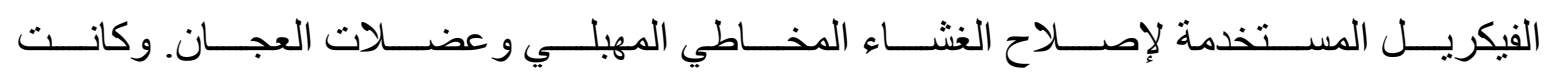

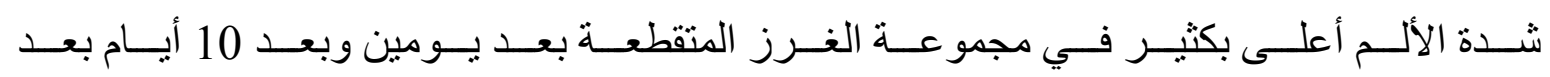

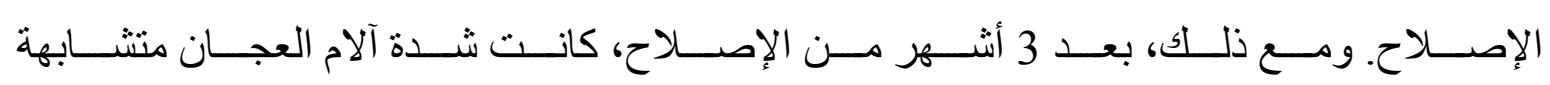




\section{A COMPARATIVE STUDY OF CONTINUOUS VERSUS INTERRUPTED... 1739}

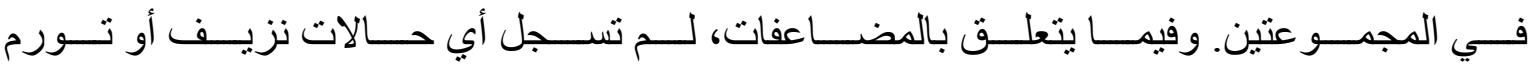

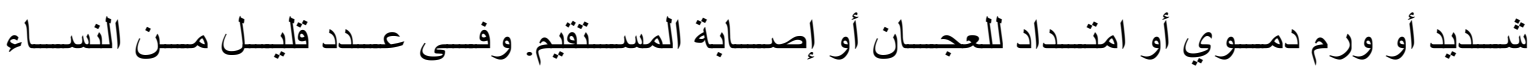

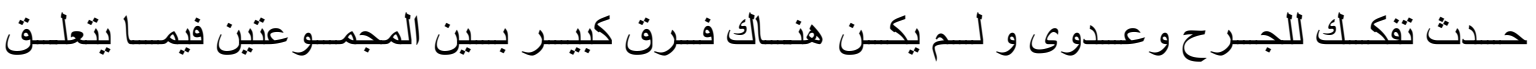

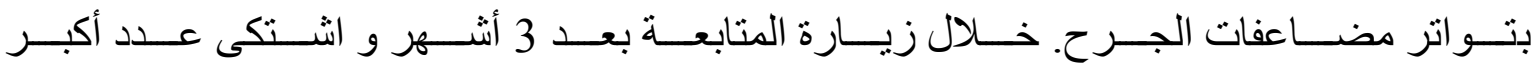
مــن النســاء مــن عســر الجمـــاع فــي مجموعـــة الغــرز المتقطعــة مــع فــرق غيــر دال إحصائياً.

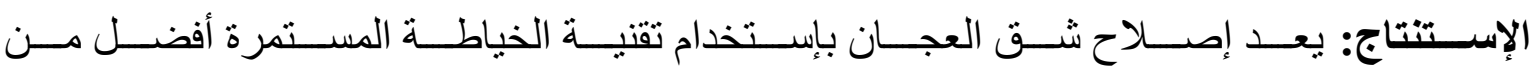

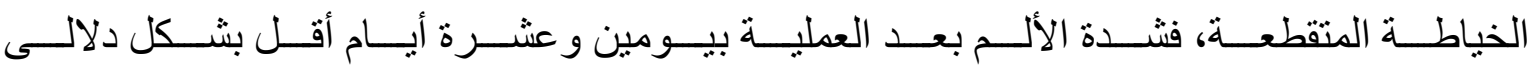

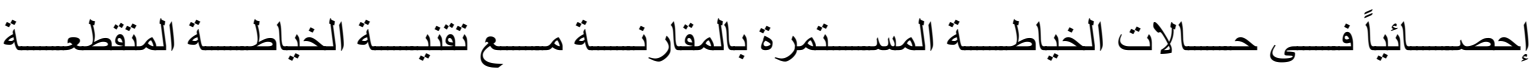

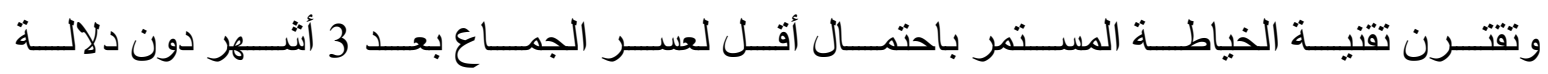

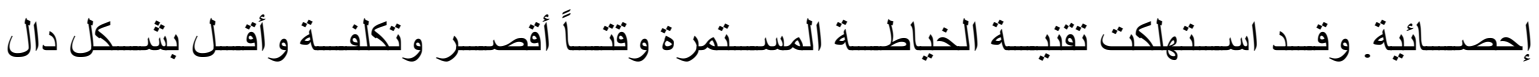
إحصائياً. 